\title{
China faces increased spread of HIV
}

After years of concealing the existence of sexually transmitted diseases (STDs), prostitution, homosexuality, and growing numbers of AIDScases, the Chinese government appears to be making efforts to be more open in thehopethat it can prevent a major HIV epidemic. While AIDS and public health researchers are unanimously supportive of this move, some fear that infection rates have al ready reached epidemic proportions in the country. They say privately that Africa may pale by comparison with the situation in China.

One of the first signs that the Chinese government was implementing new measures to tackle HIV was the announcement that the sale of blood for transfusion was to be banned beginning October 1st (Nature Med., 4, 139; 1998). Around 17 percent of HIV positive individuals in China were infected via transfusion.

But according to Yichen Lu, director of virology at Avant Immunotherapeutics, Massa-

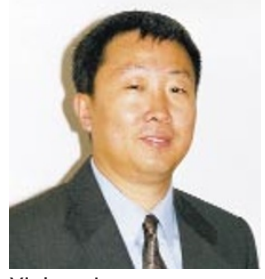
Yichen Lu
AIDS Day. Two years ago, this kind of display would be "unthinkable," says Lu.

Perhaps one of the most difficult steps that China has taken is disclosing the size of theHIV problem. At a speech at the13th International AIDS Congress in Geneva, China's vice minister of public health, Dakui Yin, revealed theextent of infection. From the time that the first case of HIV infection was identified, up until March 1998, more than 10 million Chinese were tested for HIV antibodies, said Yin. Of these, 9,970 tested positive 3217 of them in 1997. There were 290 confirmed cases of AIDS and 173 deaths from AIDS. Yunnan Province, which is adjacent to Myanmar (formerly Burma), has the greatest number of infection cases. Yin told the audience that intravenous drug users constitute 67 percent of all HIV infections. Yin stated that China's mission "is to keep the number of HIV infections bel ow 1.5 million by $2010 . "$

Unfortunately, thesenumbers may begross underestimates. "It is now said there are 200,000 close links with his home country in an effort to assist using his expertisein HIV, the government is doing much more.

As Nature M edicine went to press, China was among several Southeast Asian nations that participated in a conference held in Tokyo to discuss the possibility of developing an HIV vaccine for the region. Participants at the meeting entitled "AIDSVaccines in Asia, Needs and Opportunities," organized by UNAIDS and the World Health Organization, included one highlevel public health official and one senior scientist from each country. Epidemiologist Shao Yiming, a member of China's N ational Expert Committeeon AIDS, and Li Heming, chair of theChineseAIDSVaccineGroup of the Chinese Academy of Preventive M edicine (CAPM), represented China. Western representatives were believed to include Peggy Johnston, newly appointed Assistant Director for AIDS vaccines at the US National Institute of Allergy and Infectious Diseases.

Some Western AIDS researchers have been invited to the country to help set up diagnostic facilities and a Chinese Foundation for Prevention of STD and AIDS has been created, chaired by Zeng Yi, chief of the Department of Tumor Viruses and HIV at CAPM. This foundation will sponsor a public health education exhibition in Beijing in December, in concert with World cases or more, and WHO estimates 400,000," says HIV researcher David Ho, director of the Aaron Diamond AIDS Research Center at Rockefeller University in New York. Ho, who has traveled to China each year for the past five or six years, explains that when he first began visiting China, "the epidemic was said to be less than 1000 cases, over 90 percent of them localized to Yunnan Province." Now cases
Six weeks ago, a comparatively unknown organization held a cancer research conferencein Washington D.C. to celebratethe 25th anniversary of its inauguration. The National Foundation for Cancer Research (NFCR) speaker list included some of the most senior names in basic biomedical research in theworld, testimony to thefact that in these times of big budget science, a minimal amount of funding for the right 'risk project' can pay large dividends.

NFCR grantees include Nobel Prize winners Cesar Milstein and Sir Aaron Klug, and such distinguished researchers as Leo Sachs (Weizman Institute of Science, Israel), Kathryn Horwitz (University of Colorado), Esther Chang (Georgetown University) and Manfred Raj wesky (University of Essen, Germany). Entertainment during the meeting was provided by Bert Vogelstein's band have been reported in Xinjiang Provincein the northwest and Anhui and Hebei provincesin central China.

Roger Detels of the University of California, Los Angeles, who has been working with the Chinese since the late 1980s to develop a Ph.D. training program for $\mathrm{Chi}$ nese health professionals, says that the different nature of drug users in China means that China faces the opposite flow to most countries-infection began in rural areas and is spreading to urban sites. Detels believes that even though the Chinese"may not be forthcoming in terms of numbers, it doesn't mean they don't know what the real numbers are."

Lu agrees: "Thereisindirect evidencethat indicates the potential HIV-1 epidemic in China may be more devastating." In 1997 there were 461,510 reported cases of STDs in China. This, says Lu, "makes it thethird most preval ent infectious disease group in China, following dysentery and hepatitis." He adds that, "It's almost certain that the reported STD cases represent only a fraction of the infected population."

Whatever thereality of theepidemic, Lu, like others, thinks that China is genuinely trying to tackle the problem at the highest levels of the government. "State Councilor Peng Peiyun suggested in a public speech that 'we should take AIDS control work to be as important as safeguarding our nation,'" states Lu. "The official English translation of the Chinese word in this speech was 'safeguarding,' but I really think it wasmeant to be 'saving' or 'rescuing from disasters."'

Myrna Watanabe, Connecticut

\section{High risk research funding can be high profile}

'Wild Type'. Vogelstein (Howard Hughes Medical Institute, Baltimore) has also been funded by the NFCR.

American entrepreneur, Franklin Salisbury, established the NFCR in 1973 on hearing that Albert Szent-Gyorgyi, the Hungarian biochemist who received the Nobel Prize in 1937 for the identification of Vitamin $\mathrm{C}$ and the co-discovery of the Krebs cycle, was struggling to fund research into cancer cell growth. Salisbury mail ed a check for $\$ 25$ to Szent-Gyorgyi, and was so overwhel med to receive a letter of thanks that he not only provided substantial funding for Szent-Gyorgyi's work, but also decided to establish a philanthropic fund to support other basic cancer researchers.

Since that time, the NFCR, which raises funds through mail donations averaging $\$ 14$, has given $\$ 160$ million to research. 